TITLE:

\title{
Mild and Chemoselective Thioacylation of Amines Enabled by the Nucleophilic Activation of Elemental Sulfur
}

\section{$\operatorname{AUTHOR}(\mathrm{S}):$}

Saito, Masato; Murakami, Sho; Nanjo, Takeshi; Kobayashi, Yusuke; Takemoto, Yoshiji

\section{CITATION:}

Saito, Masato ...[et al]. Mild and Chemoselective Thioacylation of Amines Enabled by the Nucleophilic Activation of Elemental Sulfur. Journal of the American Chemical Society 2020, 142(18): 8130-8135

\section{ISSUE DATE:}

2020-05-06

URL:

http://hdl.handle.net/2433/253551

\section{RIGHT:}

This document is the Accepted Manuscript version of a Published Work that appeared in final form in Journal of the American Chemical Society, copyright (c) American Chemical Society after peer review and technical editing by the publisher. To access the final edited and published work see https://doi.org/10.1021/jacs.0c03256.; The full-text file will be made open to the public on 21 April 2021 in accordance with publisher's 'Terms and Conditions for Self-Archiving'.; This is not the published version. Please cite only the published version.; この論文は出版社版でありません。引用の際 には出版社版をご確認ご利用ください。 


\title{
Mild and Chemoselective Thioacylation of Amines Enabled by the Nu- cleophilic Activation of Elemental Sulfur
}

\author{
Masato Saito, Sho Murakami, Takeshi Nanjo, Yusuke Kobayashi, and Yoshiji Takemoto* \\ Graduate School of Pharmaceutical Sciences, Kyoto University, Yoshida, Sakyo-ku, Kyoto 6o6-8501, Japan \\ Supporting Information Placeholder
}

\begin{abstract}
A mild and chemoselective method for the thioacylation of amines using $\alpha$-ketoacids and elemental sulfur has been developed. The key to success for this transformation is the nucleophilic activation of elemental sulfur by thiols such as 1-dodecanethiol. A variety of functional groups, including unprotected hydroxyl, carboxyl, amide, sulfide, and tertiary amine moieties are tolerated under the applied reaction conditions. To demonstrate the advantages of this method compared to conventional $\mathrm{O}-\mathrm{S}$ exchange reactions using Lawesson's reagent or $\mathrm{P}_{2} \mathrm{~S}_{5}$, thioamide moieties were introduced sitespecifically into biologically active compounds.
\end{abstract}

Thioamide moieties are commonly encountered in synthetic intermediates. Their synthetic validity is due to their unique reactivity and their ability to serve as building blocks in the synthesis of $S$-containing heterocycles such as thioazoles and thioazolines., ${ }^{1,2}$ In addition, thioamides are regarded as bioisosteres of amides that exhibit increased resistance to enzymatic hydrolysis; 3 many articles have described an improved biological activity of pharmaceuticals upon replacing amide with thioamide groups. ${ }^{4}$ For instance, thioacyl lysine derivatives possess significantly improved anticancer properties compared to acyl lysines. ${ }^{4 a}$ Furthermore, Petersson reported that the incorporation of thioamides into peptides provides stability against hydrolysis by proteases without any loss of biological activity. ${ }^{4 \mathrm{~b}}$ Although various methods for the synthesis of valuable thioamides have been developed, reliable methods for the site-specific installation of thioamides with good functional-group compatibility remain elusive. ${ }^{-5}$ 7 Conventionally, $\mathrm{O}-\mathrm{S}$ exchange reactions in oligoamides are accomplished with Lawesson's reagent or $\mathrm{P}_{2} \mathrm{~S}_{5}$, albeit that this generally results in a mixture of partially converted oligothioamides that may, depending on the reaction conditions, contain unreacted amides (Scheme $1 \mathrm{~A}$ ). ${ }^{5}$ While the Willgerodt-Kindler reaction and many variations thereof (Scheme $\left.{ }_{1 B}\right)^{6}$ require only carbonyl compounds, amines, and elemental sulfur, most of these reactions proceed exclusively under relatively harsh conditions and exhibit a severely limited substrate scope. Even though significant effort has been devoted to solving these fundamental problems, 7 the reported methods often suffer from poor site-selectivity and functional-group compatibility. Accordingly, mild and efficient reactions for the chemoselective formation of thioamides with broad functionalgroup tolerance are highly desirable.
Scheme 1. Decarboxylative thioacylation strategies

(A) O-S exchange by Lawesson's reagent or $\mathrm{P}_{2} \mathrm{~S}_{5}$

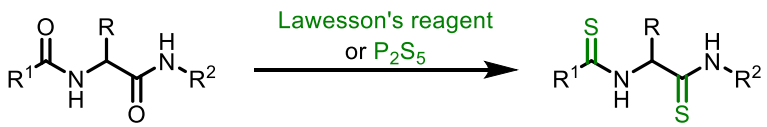

(B) Willgerodt-Kindler-type reactions

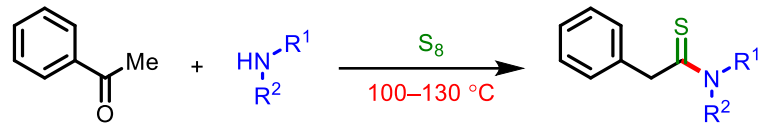

(C) Decarboxylative thioacylation under mild conditions (this work)

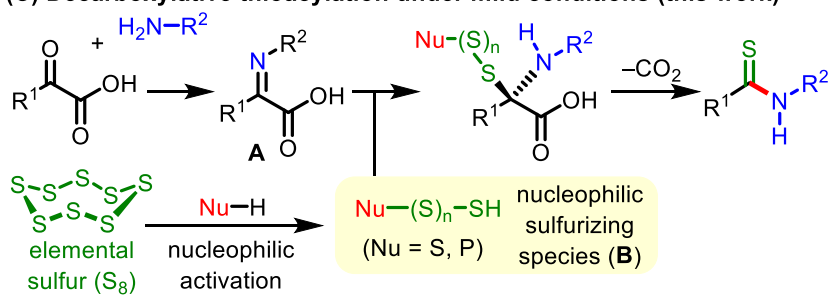

Herein, we propose such a chemoselective synthesis of thioamides under mild conditions, inspired by our previous work on the decarboxylative synthesis of amides ${ }^{8,9}$ using $\alpha$-ketoacids, amines, and $t$-butylhydroperoxide (TBHP) via the nucleophilic addition of TBHP to imine intermediate $\mathbf{A}$. We envisaged that thioamides could potentially be obtained using a nucleophilic sulfurizing oxidant of the type $\mathrm{R}^{-} \mathrm{S}_{\mathrm{n}}-\mathrm{S}-\mathrm{H}$ instead of TBHP (Scheme ${ }_{1} \mathrm{C}$ ). Alas, compared to electrophilic sulfurizing reagents, such nucleophilic reagents are scarce..$^{10}$ Accordingly, we planned to activate elemental sulfur using nucleophiles $(\mathrm{Nu})$ to generate nucleophilic sulfurizing species $\mathbf{B}$, which bears a Nu- $\mathrm{S}_{\mathrm{n}}-\mathrm{S}-$ $\mathrm{H}$ moiety. However, elemental sulfur ${ }^{11}$ is generally stable under ambient conditions, and its activation usually requires harsh conditions (acids, bases, or radical initiators 
at high temperatures). In order to effectively produce thioamides, we activated elemental sulfur under mild conditions using strong or soft nucleophiles such as thiols or phosphines $(\mathrm{Nu}=S, P)$. Furthermore, chalcogen-chalcogen interactions ${ }^{12}$ are expected to aid the nucleophilic activation of elemental sulfur using thiols $(\mathrm{Nu}=S)$.

Table 1. Optimization of the reaction conditions for the decarboxylative thioacylation

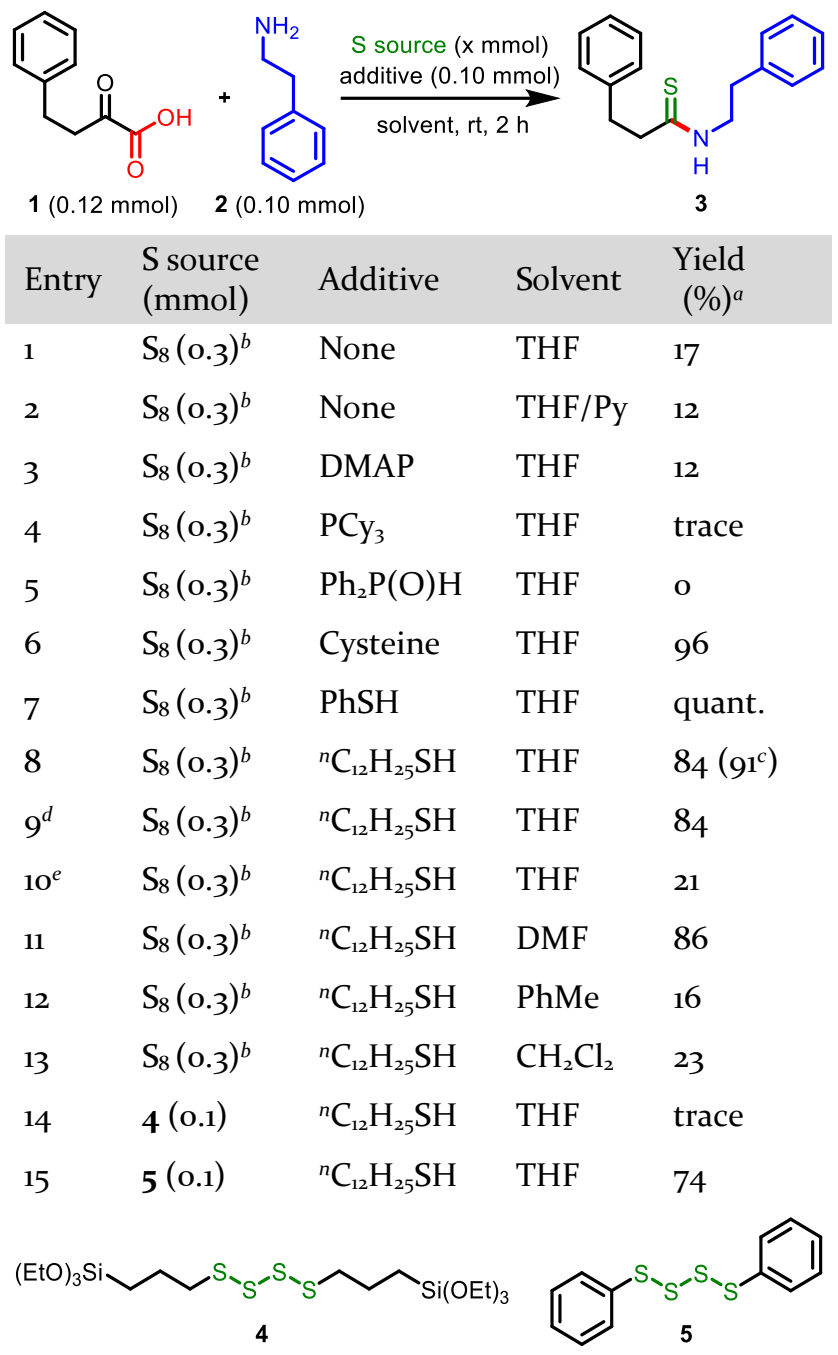

${ }^{a}$ The yield was determined by ${ }^{1} \mathrm{H}$ NMR spectroscopy using dimethyl terephthalate as the internal standard. ${ }^{b}$ The number of mmols was calculated as the number of $\mathrm{S}$ atoms. 'Isolated yield. ${ }^{d} \mathrm{O}$ mol\% ${ }^{n} \mathrm{C}_{12} \mathrm{H}_{25} \mathrm{SH}$ was employed. ${ }^{e}$ o equiv. ${ }^{n} \mathrm{C}_{12} \mathrm{H}_{25} \mathrm{SH}$ was employed.

Initially, the reaction conditions were optimized using $\alpha$-ketoacid 1, phenethylamine 2, and elemental sulfur as substrates (Table 1 ). When the reaction was carried out in THF without an additive, the obtained yield of the desired product (3) was low (entry 1). Subsequently, we examined nucleophilic additives using THF as the solvent (entries 28). Although pyridine, DMAP, and $\mathrm{PC}_{3}$ did not improve the yield of 3 at room temperature (entries 2-4), the addition of thiols (cysteine, thiophenol, and 1-dodecanethiol $\left.\left({ }^{n} \mathrm{C}_{12} \mathrm{H}_{25} \mathrm{SH}\right)\right)$ significantly improved the reaction at room temperature and afforded 3 in excellent yield (entries 6-8). Considering price and odor, we chose ${ }^{n} \mathrm{C}_{12} \mathrm{H}_{25} \mathrm{SH}$ as the optimal additive (entry 8). ${ }^{13}$ While the reaction proceeded with as little as $10 \mathrm{~mol} \%{ }^{n} \mathrm{C}_{12} \mathrm{H}_{25} \mathrm{SH}$ (entry 9), the thioacylation was hampered by an excess of ${ }^{n} \mathrm{C}_{12} \mathrm{H}_{25} \mathrm{SH}$ (entry 10); this may indicate that excess thiol causes a fragmentation of $\mathrm{S}_{8}$ to produce unreactive species. Next, we considered the solvent; DMF produced 3 in high yield (entry 11), whereas less polar solvents such as toluene and dichloromethane produced 3 in merely low yield, even in the presence of thiols (entries 12,13), which can be explained by the poor solubility of $S_{8}$ in these solvents. Finally, we substituted elemental sulfur with several different polysulfides in order to gain further insights on the reactive species in this thioacylation reaction (entries 14, 15). While commercially available dialkyltetrasulfide 4 was not effective for the thioacylation, 3 was produced in $74 \%$ yield using diaryltetrasulfide $5 .{ }^{14}$ These results suggest that thiols activate polysulfide S-S bonds and attack the $\alpha$-sulfur of tetrasulfides to provide reactive RSSSH species. ${ }^{15}$

With the optimum reaction conditions in hand, we investigated the substrate scope of the thioamidation reaction between $\alpha$-ketoacids and amines in order to verify the chemoselectivity and functional-group tolerance (Table 2 ). $\alpha$-Ketoacids with linear or branched alkyl substituents provided thioamides 6 and 7 in good yield (Table $2 A$ ). In contrast, $\alpha$-ketoacids derived from benzoic acids produced thioamides 8 and $\mathbf{9}$ in moderate yield, even when heated, which is presumably due to their lower reactivity. Interestingly, when oxaloacetic acid was used as an acyl source, thioacetylated 10 was obtained in $70 \%$ yield via decarboxylation. Our general thioamidation protocol is also applicable to substrates with unprotected $\mathrm{OH}$ groups (11). Next, we explored the scope with respect to amines. Cyclohexylamine, and secondary cyclic amines, such as piperidine and morpholine, provided thioamides 12-14 in 78-100\% yield. In addition, primary amines that bear an additional tertiary amine, iodine, fluorine, or chlorine group(s) provided thioamides 15-18 in good yield. Although the aniline derivatives showed lower nucleophilic activity, $p$-toluidine produced thioanilide 19 in $47 \%$ yield. As unsaturated bonds in e.g. alkynes react with elemental sulfur under basic conditions, we also tested alkynes and olefins under the optimized reaction conditions, which provided $\mathbf{2 0 - 2 4}$ in $47^{-}$ $81 \%$ yield. It should be noted here that $\mathbf{2 0 - 2 4}$ contain unprotected hydroxyl and carboxyl groups, which could potentially be functionalized by coupling and/or substitution reactions. Finally, amoxapine, an antidepressant drug, furnished thioamidated derivative 25 in $84 \%$ yield, which offers a method for prodrug synthesis via thioacylation. ${ }^{16}$

To further investigate the functional-group tolerance, we applied various amino-acid derivatives as nucleophiles. Esters of phenylalanine, leucine, and alanine were thioacylated under the optimized conditions to produce $\mathbf{2 6 - 2 8}$ in $66-77 \%$ yield, even when in-situ-neutralized amine hydrochloride salts were employed in the reaction. Bulkier amino acids, such as valine, tertiary leucine, and isoleucine motifs, provided 29-31 in 56-75\% yield. 
Table 2. Substrate scope of the decarboxylative thioacylation ${ }^{a}$

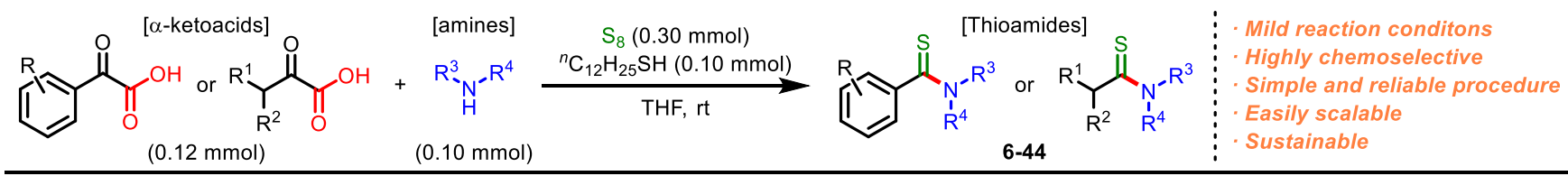

(A) Scope of $\alpha$-ketoacids and amines
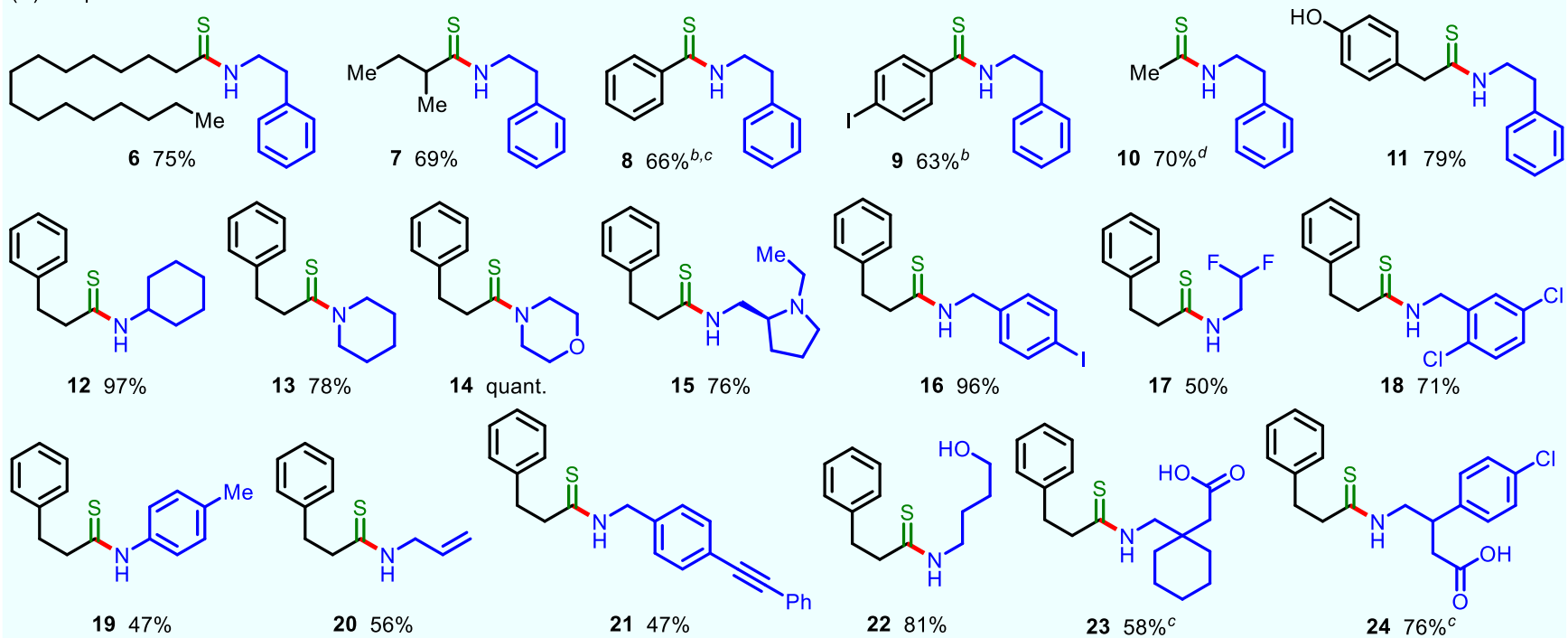<smiles>COC(=O)C(NC(=S)CCc1ccccc1)C(C)(C)C</smiles><smiles>CC1=Nc2ccccc2Oc2ccc(Cl)cc21</smiles><smiles>O=C(OCc1ccccc1)C(Cc1ccccc1)NC(=S)CCc1ccccc1</smiles><smiles>[R7]C(=O)NC(CC(=S)NC(=O)Cc1ccccc1)C(=O)OCc1ccccc1</smiles><smiles>COC(=O)C([Mg])NC(=S)CCc1ccccc1</smiles>

$2877 \%$,e<smiles>CC(C)C(NC(=S)CCc1ccccc1)C(=O)OC(C)(C)C</smiles>

$2975 \%$,e
$3060 \%$,e<smiles>CC[C@H](C)[C@H](NC(=S)CCc1ccccc1)C(=O)OC</smiles>

$3156 \%{ }^{c, e}$

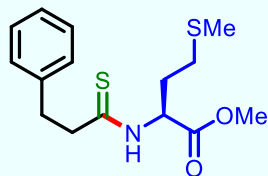

$3264 \%^{c, e}$

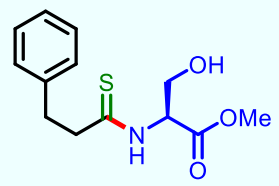

$3387 \%$,e

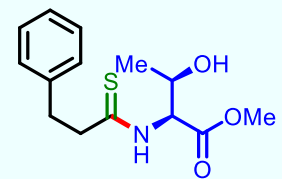

$3463 \%$,e<smiles>CC(C)(C)OC(=O)C(Cc1ccc(O)cc1)NC(=S)CCc1ccccc1</smiles>

$3589 \%$,<smiles>O=C(OCc1ccccc1)C1CCCN1C(=S)CCc1ccccc1</smiles>

$3667 \%^{c, e}$<smiles>COC(=O)C(Cc1c[nH]cn1)NC(=S)CCc1ccccc1</smiles>

$3777 \%^{c, e}$<smiles>COC(=O)C(Cc1c[nH]c2ccccc12)NC(=S)CCc1ccccc1</smiles>

$3851 \%^{c, e}$

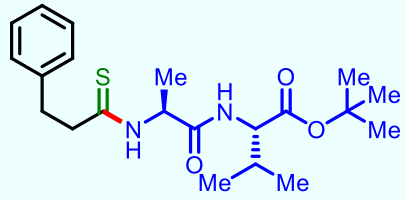

$3955 \%{ }^{b, c, e}$<smiles>COC(=O)C(NC(=S)[C@H](CC(C)C)NC(=O)O)C(C)C</smiles>

$4050 \%, d r=95: 5^{f, g, h}$

(B) Potential pharmaceutical compounds<smiles>O=C1CCC(NC(=S)Cc2ccc(O)cc2)C(=O)N1</smiles>

$4179 \%[2.9 \text { g scale }]^{c, e, i}$ Transcriptional antiestrogen $S$-analogue<smiles>N#CCC(=S)N1CCC(NC(=O)Nc2ccc(C(F)(F)F)cc2)CC1</smiles>
Analgesic $S$-analogue<smiles>O=C(NCCC(=S)NC1CCCc2ccccc21)c1ccc(OC(F)(F)F)cc1</smiles>

$4382 \%, c$

ML390 S-analogue<smiles>S=C(NC1CCN(Cc2ccccc2)CC1)c1ccc(I)cc1</smiles>

$444 \%^{b, c}$

4-IBP S-analogue

${ }^{a}$ Isolated yield. ${ }^{b}$ The reaction was performed at $50{ }^{\circ} \mathrm{C}$. ${ }^{c}$ The reaction was performed in DMF. ${ }^{d}$ Oxaloacetic acid was used as the $\alpha-$ ketoacid. ${ }^{e}$ Amine hydrochloride salt (o.10 mmol) and ${ }^{i} \mathrm{Pr}_{2} \mathrm{NEt}$ (0.10-0.20 mmol) were used. $f_{\alpha}$-Ketoacid (o.10 mmol), amine (o.12 $\mathrm{mol})$, and 5-tert-butyl-2-methylbenzenethiol (o.10 mmol) were reacted in DMF/CS $(9: 1) .{ }^{g} \mathrm{~A}$ solution of the amine and the thiol was added dropwise over 4 hours at $80^{\circ} \mathrm{C}$. ${ }^{h} \mathrm{Dr}$ values were estimated by chiral SFC analysis. ${ }^{i}$ The reaction was performed at $8 \mathrm{o}^{\circ} \mathrm{C}$. 
Scheme 2. Synthetic applications of the decarboxylative thioacylation of amines ${ }^{a}$

(A) Rapid constuction of bioactive thiazoline scaffolds
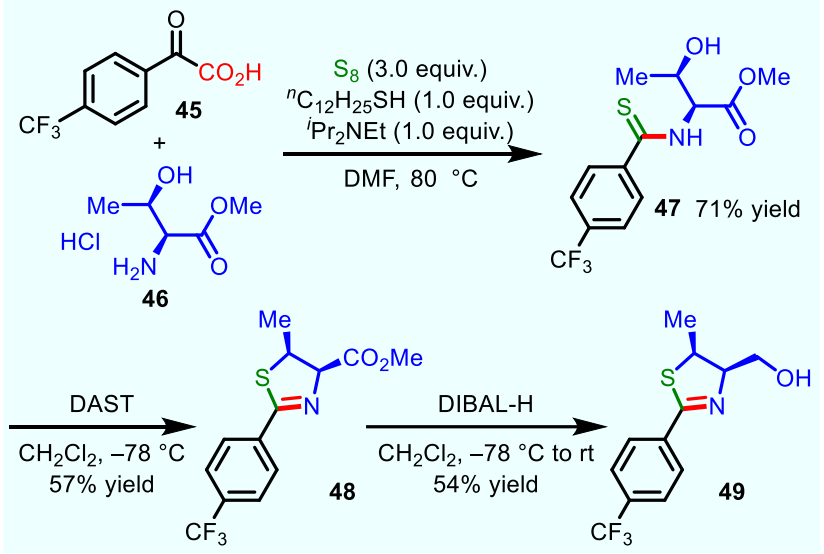

(B) Synthesis of thiomyristoyl lysine (TM) exhibiting anticancer properties

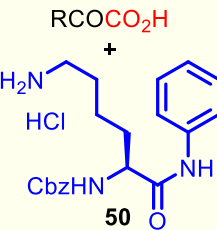

$\mathrm{S}_{8}(3.0$ equiv.) ${ }^{n} \mathrm{C}_{12} \mathrm{H}_{25} \mathrm{SH}$ (1.0 equiv.) ${ }^{i} \mathrm{Pr}_{2} \mathrm{NEt}(1.0$ equiv.)<smiles>CCCCCCCCCC(=S)NCCCC[C@H](NC(=O)OC(C)(C)C)C(=O)Nc1ccccc1</smiles><smiles>NC(=S)CCc1ccccc1</smiles><smiles>O=C(Nc1ccccc1)NC(CCCCNC(=S)c1ccc(C(F)(F)F)cc1)C(=O)Nc1ccccc1</smiles>
51 (TM) $80 \%$ yield

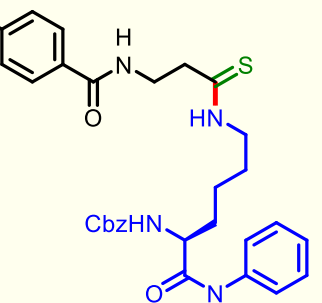

$5276 \%$ yield $\mathrm{H}$

$5364 \%$ yield $^{b} \mathrm{H}$

$5453 \%$ yield $^{c} \mathrm{H}$

(C) Site-specific thioamide bond formation of a primary amide-containing molecule
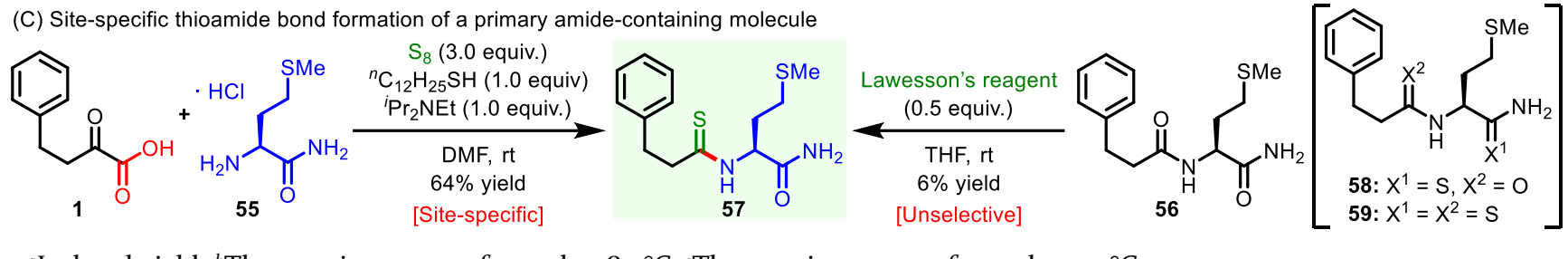

${ }^{a}$ Isolated yield. ${ }^{b}$ The reaction was performed at $80^{\circ} \mathrm{C}$. ${ }^{c}$ The reaction was performed at $50^{\circ} \mathrm{C}$.

Notably, methionine derivative 32 was obtained in $64 \%$ yield without oxidation of the sulfide moiety. In addition, this reaction was applicable to amino acids with unprotected hydroxyl groups (serine, threonine, and tyrosine) to produce thioamides 33-35 in good yield. Proline, $\mathrm{N}$-unprotected histidine, tryptophan, and dipeptide derivatives furnished thioacylated $36-39$ in $51-77 \%$ yield. Moreover, the thioacylation using an $\alpha$-ketoacid derived from Cbz-leucine enabled the rapid preparation of peptide thioamide $\mathbf{4 0 .}$

Subsequently, we applied this method to synthesize thioamide analogues of pharmaceutical compounds that contain amide groups (Table $2 \mathrm{~B}$ ). A transcriptional antiestrogen $^{17} S$-analogue (41), an analgesic ${ }^{18} S$-analogue (42), a human dihydroorotate dehydrogenase inhibitor ${ }^{19}$ analogue (43), and a selective $\sigma 1$ agonist $^{20}$ analogue (44) were obtained in $40-82 \%$ yield. Notably, our thioamidation protocol is highly reliable and scalable; for example, $\mathbf{4 1}$ could be produced on the gram scale (79\% yield, $2.9 \mathrm{~g}$ ) without the need for any special operational requirements or safety measures.

To demonstrate its synthetic utility, we applied this chemoselective thioacylation reaction to the synthesis of several biologically active compounds (Scheme $2 \mathrm{~A}$ and $2 \mathrm{~B}$ ). Thiazoline scaffolds with an aromatic ring at the $\mathrm{C}-2$ position are common in various biologically active compounds, including natural products such as pulicatins ${ }^{21}$ and the highly potent human peroxisome proliferator-activated receptor- $\delta$ agonist. ${ }^{22}$ The decarboxylative thioacylation between $\mathbf{4 5}$ and threonine derivative $\mathbf{4 6}$ furnished thioamide 47 in $71 \%$ yield, which was directly converted into thiazoline 49 after treatment with $N, N$-diethylaminosulfur trifluoride (DAST), followed by reduction with DIBAL-H
(Scheme 2A). Furthermore, the synthesis of thioacylated lysine compounds, which exhibit anticancer properties, was also accomplished using this thioacylation (Scheme 2B). ${ }^{4 a, d}$ Under the optimized conditions, the amine moiety of a lysine residue was thioacylated using an $\alpha$-ketoacid derived from myristic acid to obtain thiomyristoyl lysine (TM) compound $\mathbf{5 1}$ in $80 \%$ yield. The synthesis of thioamide analogues 52-54 with different thioacyl groups was straightforward, as various $\alpha$-ketoacids are commercially available or easily prepared. ${ }^{23}$ Finally, we wanted to demonstrate the synthetic advantages of our decarboxylative thioacylation compared to conventional $O-S$ exchange reactions (Scheme $2 \mathrm{C}$ ). The decarboxylative thioamidation between 1 and $\mathbf{5 5}$ produced thioamide $\mathbf{5 7}$ in $64 \%$ yield, while the $O-S$ exchange reaction of $\mathbf{5 6}$ using Lawesson's reagent resulted in a mixture of 57-59 (mono- or di-thioamides), which is due to the similar reactivity of the amides. These results strongly indicate that this decarboxylative thioacylation strategy is a powerful tool for the selective introduction of a thioamide moiety into molecules that contain several amide bonds.

In conclusion, we have developed a mild and highly chemoselective method for the thioacylation of amines with $\alpha$-ketoacids. The key to this methodology is the efficient activation of elemental sulfur under mild conditions by thiols. These conditions tolerate a wide variety of functional groups that include unprotected alcohols, phenols, unsaturated bonds, and carboxylic acids. We believe that a site-selective introduction of thioamide moieties into biologically active compounds, including peptides and proteins, will promote structure-activity-relationship and 
drug-discovery studies. Studies of this nature are currently in progress in our laboratory.

\section{ASSOCIATED CONTENT}

\section{Supporting Information}

The Supporting Information is available free of charge on the ACS publications website.

Experimental procedures and analytical data for all new compounds (PDF)

\section{AUTHOR INFORMATION}

\section{Corresponding Author}

*E-mail: takemoto@pharm.kyoto-u.ac.jp

\section{ORCID}

Masato Saito: oooo-0oo1-79o8-0776

Takeshi Nanjo: oooo-0oo2-5679-6701

Yusuke Kobayashi: oooo-0oo3-3074-7378

Yoshiji Takemoto: oooo-0oo3-1375-3821

\section{Notes}

The authors declare no competing financial interests.

\section{ACKNOWLEDGMENTS}

This work was supported by JSPS KAKENHI grants JP16Ho6384 and JP18K14865. The authors gratefully acknowledge a Grant for Basic Science Research Projects from The Sumitomo Foundation (T.N.), the Hoansha Foundation for a research grant (Y.K.), and a Grant-in-Aid for JSPS Fellows (M.S.).

\section{REFERENCES}

(1) For reviews on thioamides in organic synthesis, see: (a) Jagodziński, T. S. Thioamides as Useful Synthons in the Synthesis of Heterocycles. Chem. Rev. 2003, 103, 197-227. (b) Hughes, R. A.; Moody, C. J. From Amino Acids to Heteroaromatics-Thiopeptide Antibiotics, Nature's Heterocyclic Peptides. Angew. Chem., Int. Ed. 2007, 46, 7930-7954. (c) Murai, T.; Mutoh, Y. Thioamides and Thioformamides for Sequential Reactions with Organolithium and Grignard Reagents. Chem. Lett. 2012, 41, 2-8. (d) Kumagai, N.; Shibasaki, M. Cooperative Asymmetric Catalysis Using Thioamides toward Truly Practical Organic Syntheses. Isr. J. Chem. 2012, 52, 604-612. (e) Tang, K.-X.; Wang, C.-M.; Gao, T.-H.; Chen, L.; Fan, L.; Sun, L.-P. Transition Metal-Catalyzed C-H Bond Functionalizations by Use of Sulfur-Containing Directing Groups. Adv. Synth. Catal. 2019, 361, 26-38.

(2) For selected reports on reactions involving thioamides, see: (a) Tokuyama, H.; Yamashita, T.; Reding, M. T.; Kaburagi, Y.; Fukuyama, T. Radical Cyclization of 2-Alkenylthioanilides: A Novel Synthesis of 2,3-Disubstituted Indoles. J. Am. Chem. Soc. 1999, 121, 3791-3792. (b) Hughes, R. A.; Thompson, S. P.; Alcaraz, L.; Moody, C. J. Total Synthesis of the Thiopeptide Antibiotic Amythiamicin D. J. Am. Chem. Soc. 2005, 127, 15644-15651. (c) Murai, T.; Asai, F. Three-Component Coupling Reactions of Thioformamides with Organolithium and Grignard Reagents Leading to Formation of Tertiary Amines and a Thiolating Agent. J. Am. Chem. Soc. 2007, 129, 780-781. (d) Suzuki, Y.; Yazaki, R.; Kumagai, N.; Shibasaki, M. Direct Catalytic Asymmetric Mannich-Type Reaction of Thioamides. Angew. Chem., Int. Ed. 2009, 48, 5026-5029. (e) Yazaki, R.; Kumagai, N.; Shibasaki, M. Direct Catalytic Asymmetric Conju- gate Addition of Terminal Alkynes to $\alpha, \beta$-Unsaturated Thioamides. J. Am. Chem. Soc. 2010, 132, 10275-10277. (f) Iwata, M.; Yazaki, R.; Chen, I.-H.; Sureshkumar, D.; Kumagai, N.; Shibasaki, M. Direct Catalytic Enantio- and Diastereoselective Aldol Reaction of Thioamides. J. Am. Chem. Soc. 2011, 133, 5554-556o. (g) Koduri, N. D.; Scott, H.; Hileman, B.; Cox, J. D.; Coffin, M.; Glicksberg, L.; Hussaini, S. R. Ruthenium Catalyzed Synthesis of Enaminones. Org. Lett. 2012, 14, 440-443. (h) Pourvali, A.; Cochrane, J. R.; Hutton, C. A. A New Method for Peptide Synthesis in the $\mathrm{N} \rightarrow \mathrm{C}$ Direction: Amide Assembly Through Silver-Promoted Reaction of Thioamides. Chem. Commun. 2014, 5o, 15963-15966. (i) Jain, P.; Verma, P.; Xia, G.; Yu, J.-Q. Enantioselective Amine $\alpha$-Functionalization via Palladium-Catalyzed $\mathrm{C}-\mathrm{H}$ Arylation of Thioamides. Nat. Chem. 2017, 9, 140-144. (j) Thombare, V. J.; Hutton, C. A. Rapid, Traceless, AgI-Promoted Macrocyclization of Peptides Possessing an N-Terminal Thioamide. Angew. Chem. Int. Ed. 2019, 58 , 4998-5002. (k) Saito, M.; Kobayashi, Y.; Takemoto, Y. Divergent and Chemoselective Transformations of Thioamides with Designed Carbene Equivalents. Chem.-Eur. J. 2019, 25, 10314-10318.

(3) For reviews on thioamides as amide bioisosteres, see: (a) Mahanta, N.; Szantai-Kis, D. M.; Petersson, E. J.; Mitchell, D. A, Biosynthesis and Chemical Applications of Thioamides. ACS Chem. Biol. 2019, 14, 142-163. (b) Choudhary, A.; Raines, R. T. An Evaluation of Peptide-Bond Isosteres. ChemBioChem 2011, 12, 1801-1807. (4) For selected reports on the effect of introducing thioamide groups into bioactive molecules, see: (a) Jing, H.; Hu, J.; He, B.; Negron Abril, Y. L.; Stupinski, J.; Weiser, K.; Carbonaro, M.; Chiang, Y.-L.; Southard, T.; Giannakakou, P.; Weiss, R. S.; Lin, H. A SIRT2-Selective Inhibitor Promotes c-Myc Oncoprotein Degradation and Exhibits Broad Anticancer Activity. Cancer Cell 2016, 29, 297-310. (b) Chen, X.; Mietlicki-Baase, E. G.; Barrett, T. M.; McGrath, L. E.; Koch-Laskowski, K.; Ferrie, J. J.; Hayes, M. R.; Petersson, E. J. Thioamide Substitution Selectively Modulates Proteolysis and Receptor Activity of Therapeutic Peptide Hormones. J. Am. Chem. Soc. 2017, 139, 16688-16695. (c) Verma, H.; Khatri, B.; Chakraborti, S.; Chatterjee, J. Increasing the Bioactive Space of Peptide Macrocycles by Thioamide Substitution. Chem. Sci. 2018, 9, 2443-2451. (d) Spiegelman, N. A.; Hong, J. Y.; Hu, J.; Jing, H.; Wang, M.; Price, I. R.; Cao, J.; Yang, M.; Zhang, X.; Lin, H. A SmallMolecule SIRT2 Inhibitor That Promotes K-Ras4a Lysine FattyAcylation. ChemMedChem 2019, 14, 744-748.

(5) (a) Thomsen, I.; Clausen, K.; Scheibye, S.; Lawesson, S.-O. Thiation with 2,4-Bis(4-methoxyphenyl)-1,3,2,4-dithiadiphosphetane 2,4-Disulfide: N-Methylthiopyrrolidone. Org. Synth. 1984, 62, 158. (b) Ozturk, T.; Ertas, E.; Mert, O. Use of Lawesson's Reagent in Organic Syntheses. Chem. Rev. 2007, 107, 5210-5278.

(6) (a) Willgerodt, C. Ueber die Einwirkung von gelbem Schwefelammonium auf Ketone und Chinone. Ber. Dtsch. Chem. Ges., 1887, 20, 2467-2470. (b) Kindler, K. Studien über den Mechanismus chemischer Reaktionen. Erste Abhandlung. Reduktion von Amiden und Oxydation von Aminen. Liebigs Ann. Chem. 1923, 431, 187-230. (c) Priebbenow, D. L.; Bolm, C. Recent Advances in the Willgerodt-Kindler Reaction. Chem. Soc. Rev. 2013, 42, 7870-788o. (7) For recent publications on the synthesis of thioamides, see: (a) Nguyen, T. B.; Ermolenko, L.; Al-Mourabit, A. Efficient and Selective Multicomponent Oxidative Coupling of Two Different Aliphatic Primary Amines into Thioamides by Elemental Sulfur. Org. Lett. 2012, 14, 4274-4277. (b) Nguyen, T. B.; Tran, M. Q.; Ermolenko, L.; Al-Mourabit, A. Three-Component Reaction between Alkynes, Elemental Sulfur, and Aliphatic Amines: A General, Straightforward, and Atom Economical Approach to Thioamides. Org. Lett. 2014, 16, 310-313. (c) Guntreddi, T.; Vanjari, R.; Singh, K. N. Decarboxylative Thioamidation of Arylacetic and Cinnamic Acids: A New Approach to Thioamides. Org. Lett. 2014, 16, 36243627. (d) Mukherjee, S.; Verma, H.; Chatterjee, J. Efficient SiteSpecific Incorporation of Thioamides into Peptides on a Solid Support. Org. Lett. 2015, 17, 3150-3153. (e) Wei, J.; Li, Y.; Jiang, X. 
Aqueous Compatible Protocol to Both Alkyl and Aryl Thioamide Synthesis. Org. Lett. 2016, 18, 340-343. (f) Xu, K.; Li, Z.; Cheng, F.; Zuo, Z.; Wang, T.; Wang, M.; Liu, L. Transition-Metal-Free Cleavage of $\mathrm{C}-\mathrm{C}$ Triple Bonds in Aromatic Alkynes with $\mathrm{S}_{8}$ and Amides Leading to Aryl Thioamides. Org. Lett. 2018, 20, 2228-2231. (g) Yang, J.; Wang, C.; Xu, S.; Zhao, J. Ynamide-Mediated Thiopeptide Synthesis. Angew. Chem., Int. Ed. 2019, 58, 1382-1386. (h) Morri, A. K.; Thummala, Y.; Adepu, R.; Sharma, G. V. M.; Ghosh, S.; Doddi, V. R. Synthesis of Substituted Thioamides from gem-Dibromoalkenes and Sodiumsulfide. Eur. J. Org. Chem. 2019, 7159-7163. (i) Maini, R.; Kimura, H.; Takatsuji, R.; Katoh, T.; Goto, Y.; Suga, H. Ribosomal Formation of Thioamide Bonds in Polypeptide Synthesis. J. Am. Chem. Soc. 2019, 141, 20004-20008. (j) Yang, J.; Wang, C.; Yao, C.; Chen C.; Hu, Y.; He, G.; Zhao, J. Site-Specific Incorporation of Multiple Thioamide Substitutions into a Peptide Backbone via Solid Phase Peptide Synthesis. J. Org. Chem. 2020. 85, 1484-1494.

(8) Nanjo, T.; Kato, N.; Zhang, X.; Takemoto, Y. A HydroperoxideMediated Decarboxylation of $\alpha$-Ketoacids Enables the Chemoselective Acylation of Amines. Chem.-Eur. J, 2019, 25, 15504-15507.

(9) For selected reports on the decarboxylative amidation of $\alpha$ ketoacids, see: (a) Bode, J. W.; Fox, R. M. and Baucom, K. D. Chemoselective Amide Ligations by Decarboxylative Condensations of $N$-Alkylhydroxylamines and $\alpha$-Ketoacids. Angew. Chem., Int. Ed. 2006, 45, 1248. (b) Carrillo, N.; Davalos, E. A.; Russak, J. A. and Bode, J. W. Iterative, Aqueous Synthesis of $\beta 3$-Oligopeptides without Coupling Reagents. J. Am. Chem. Soc. 2006, 128, 1452. (c) Lu, L.; Lippert, A. R. and Bode, J. W. Stereoretentive Synthesis and Chemoselective Amide-Forming Ligations of C-Terminal Peptide $\alpha$-Ketoacids. J. Am. Chem. Soc. 2008, 130, 4253. (d) Bode, J. W. Chemical Protein Synthesis with the $\alpha$-Ketoacid-Hydroxylamine Ligation. Acc. Chem. Res. 2017, 50, 2104. (e) Liu, J.; Liu, Q.; Yi, H.; Qin, C.; Bai, R.; Qi, X.; Lan, Y. and Lei, A. Visible-Light-Mediated Decarboxylative/Oxidative Amidation of $\alpha$-Keto Acids with Amines under Mild Reaction Conditions Using $\mathrm{O}_{2}$. Angew. Chem., Int. Ed. 2014, 53, 502. (f) Xu, W.-T.; Huang, B.; Dai, J.-J.; Zu, J. and $\mathrm{Xu}, \mathrm{H}$.-J. Catalyst-Free Singlet Oxygen-Promoted Decarboxylative Amidation of $\alpha$-Keto Acids with Free Amines. Org. Lett. 2016, 18, 3114. (g) Xu, X.-L.; Xu, W.-T.; Wu, J.-W.; He, J.-B. and Xu, H.-J. Silver-promoted decarboxylative amidation of $\alpha$-keto acids with amines. Org. Biomol. Chem. 2016, 14, 9970.

(10) Although a stable reagent containing an R-S $\mathrm{S}_{\mathrm{n}}-\mathrm{S}-\mathrm{H}$ structure has not been reported, amines are expected to activate elemental sulfur and provide a nucleophilic sulfurizing oxidant under the proposed mechanisms of Willgerodt-Kindler-type reactions, which generally require high temperature; for details, see: ref 6 .

(11) For a recent review on organic reactions that involve elemental sulfur, see: Nguyen, T. B. Recent Advances in Organic Reactions Involving Elemental Sulfur. Adv. Synth. Catal. 2017, 359, 1066-1130.

(12) Esseffar, M.; Herrero, R.; Quintanilla, E.; Dávalos, J. Z.; Jiménez, P.; Abboud, J.-L. M.; Yáñez, M.; Mó, O. Activation of the Disulfide Bond and Chalcogen-Chalcogen Interactions: An Experimental (FTICR) and Computational Study. Chem.-Eur. J. 2007, 13, 1796-1803.

(13) We confirmed that the combination of 1-dodecanthiol and elemental sulfur did not produce $S_{3}$ radical anion species, although many reports on the activation of elemental sulfur under basic conditions have proposed the generation of such $\mathrm{S}_{3}$ radical anion species. For further details, see ref. 11 and the Supporting Information.

(14) Cerda, M. M.; Hammers, M. D.; Earp, M. S.; Zakharov, L. N.; Pluth, M. D.; Applications of Synthetic Organic Tetrasulfides as $\mathrm{H}_{2} \mathrm{~S}$ Donors. Org. Lett. 2017, 19, 2314-2317.

(15) For the two modes of attack of 1-dodecanethiol in the activation of a diaryltetrasulfide ( $\alpha$-attack vs $\beta$-attack), see: ref 14 . A $\beta$ attack would provide alkyltetrasulfides, which are expected to be unreactive ( $c f$. entry 13, Table 1 ). Moreover, a change in the ${ }^{1} \mathrm{H}$ NMR spectra was not observed when dialkyltetrasulfide and thiophenol were mixed in THF- $d_{8}$. These considerations and preliminary DFT calculations support the assumption that an $\alpha$-attack on a tetrasulfide furnishes a disulfide and RSSSH species. For further details, see the Supporting Information.

(16) Nishida, C. R.; de Montellano, P. R. O. Bioactivation of Antituberculosis Thioamide and Thiourea Prodrugs by Bacterial and Mammalian Flavin Monooxygenases. Chem.-Biol. Interact. 2011, 192, 21-25.

(17) Sidell, N.; Tanmahasamut, P.; Ewing, D. E.; Hendry, L. B. Transcriptional Inhibition of the Estrogen Response Element by Antiestrogenic Piperidinediones Correlates with Intercalation into DNA Measured by Energy Calculations. J. Steroid Biochem. Mol. Biol. 2005, 96, 335-345.

(18) Lee, K. S. S.; Liu, J.-Y.; Wagner, K. M.; Pakhomova, S.; Dong, H.; Morisseau, C.; Fu, S. H.; Yang, J.; Wang, P.; Ulu, A.; Mate, C. A.; Nguyen, L. V.; Hwang, S. H.; Edin, M. L.; Mara, A. A.; Wulff, H.; Newcomer, M. E.; Zeldin, D. C.; Hammock, B. D. Optimized Inhibitors of Soluble Epoxide Hydrolase Improve in Vitro Target Residence Time and in Vivo Efficacy. J. Med. Chem. 2014, 57, 70167030.

(19) Lewis, T. A.; Sykes, D. B.; Law, J. M.; Muñoz, B.; Rustiguel, J. K.; Nonato, M. C.; Scadden, D. T.; Schreiber, S. L. Development of ML390: A Human DHODH Inhibitor That Induces Differentiation in Acute Myeloid Leukemia. ACS Med. Chem. Lett. 2016, 7, 11121117.

(20) Schmidt, H. R.; Zheng, S.; Gurpinar, E.; Koehl, A.; Manglik, A.; Kruse, A. C. Crystal Structure of the Human o1 Receptor. Nature, 2016, 532, 527-530.

(21) Lin, Z.; Antemano, R. R.; Hughen, R. W.; Tianero, M. D. B.; Peraud, O.; Haygood, M. G.; Concepcion, G. P.; Olivera, B. M.; Light, A.; Schmidt, E. W. Pulicatins A-E, Neuroactive Thiazoline Metabolites from Cone Snail-Associated Bacteria. J. Nat. Prod. 2010, 73, 1922-1926.

(22) Lee, S.-J.; Samala, M.; Woo, S. Y.; Hahn, D.; Kim, D.; Kadayat, T. M.; Jung, K.; Kim, J.; Kim, D.-S.; Kwon, S.; Kim, S.; Kim, K.-H.; Nam, S.-J.; Cho, S. J.; Chin, J. Enantioselective Synthesis of a Novel Thiazoline Core as a Potent Peroxisome Proliferator-Activated Receptor $\delta$ Agonist. ACS Omega 2018, 3, 1970-1976.

(23) $\alpha$-Ketoacids are easily prepared from the corresponding carboxylic acids through a two-step homologation using sulfur ylide, and more than one hundred $\alpha$-ketoacids are commercially available. For further details, see ref. $9 \mathrm{c}$ and the Supporting Information. 


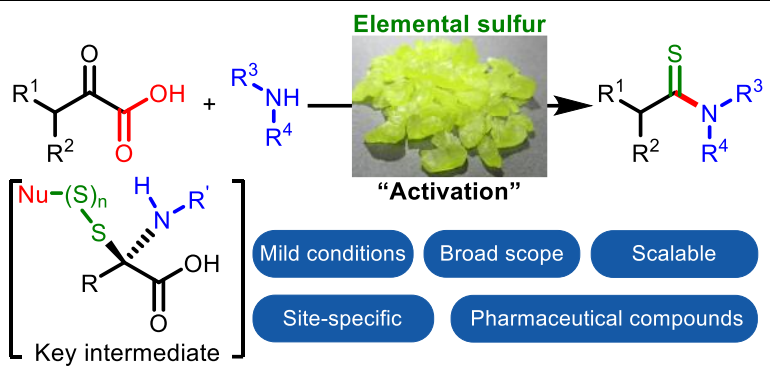

Insert Table of Contents artwork here 